NEW POLITICAL SCIENCE, 2016

VOL. $38, N O .2,272-282$

http://dx.dol.org/10.1080/07393148.2016.1153195

\title{
Buddhism, Mindfulness, and Transformative Politics
}

\author{
Matthew J. Moore \\ Department of Political Science, California Polytechnic State University, San Luis Obispo, USA
}

\begin{abstract}
This article examines whether the American cultural phenomena of the practice of Buddhism or the Buddhism-derived technique of mindfulness are likely to be helpful to the political left. It summarizes the central teachings of the ancient Buddhist texts, with particular focus on the issues of mindfulness and politics. It also reviews the political history of Buddhist countries. The author argues that although modern Buddhism has shed its historical embrace of absolutist monarchy in favor of republicanism, and although there is some ideological overlap between Buddhism and the American Left, Buddhism in America is too small a movement for it to be of much significance for progressive politics. Mindfulness appears to be capable of becoming a much larger phenomenon, but its separation from its Buddhist origins makes it also unlikely to be strategically important for the Left.
\end{abstract}

\section{Introduction}

Siddhattha Gotama, also known as the Buddha, ${ }^{1}$ developed the practice of mindfulness (sati) in the sixth-fifth centuries $\mathrm{BCE}^{2}$ as a central part of his spiritual teachings, which have subsequently developed into the religion/philosophy known as Buddhism. Today, Buddhism has some four hundred to five hundred million adherents worldwide, making it the fourth or fifth largest contemporary religion. ${ }^{3}$ As in the Vedic religion from which it developed (and which itself evolved into modern Hinduism), in Buddhism the central goal is to escape the cycle of birth-death-rebirth known as samsära by both working through the kamma (in Päli4; Sanskrit: karma) accumulated from previous incarnations and by learning not to

CONTACT Matthew J. Moore mmoore02@calpoly.edu

'The honorific title Buddha means "awakened one."

${ }^{2}$ See L.S. Cousins, "The Dating of the Historical Buddha: A Review Article," Journal of the Royal Asiatic Society Series 3, 6:1 (1996), pp. 57-63.

${ }^{3}$ The Pew Forum on Religion \& Public Life, The Global Religious Landscape: A Report on the Size and Distribution of the World's Major Religious Groups as of 2010, Pew-Templeton Global Religious Futures Project (Washington, DC: Pew Research Center, 2012), p. 9.

${ }^{4}$ The earliest Buddhist texts were written in a language called Päli, which bears roughly the same relationship to Sanskrit that Italian bears to Latin.

(2) 2016 Caucus for a New Political Science 
generate new kamma. ${ }^{5}$ Despite its apparently otherworldly focus, Buddhism has always had a political dimension. In the United States, Buddhism has increasingly become associated with the political left. This raises the question of whether and how Buddhism, and its secular offshoot, mindfulness, might relate to transformative politics.

The Buddha laid out his core teachings in his first sermon (the Dhammacakkappavattana Sutta ${ }^{6}$. The teachings begin with the Four Noble Truths. The first is that life is dukkha, which means "suffering" but also can mean something a bit less harsh: that life is inevitably and persistently unsatisfactory. The second noble truth is that suffering is caused by clinging (tanhä; the word literally means "thirst") to ideas, sensations, desires, and other phenomena of our experience. The third truth teaches that suffering can be stopped (nirodha; "cessation") by learning not to cling, and the fourth identifies following the Noble Eightfold Path as the way to cease clinging, by practicing right understanding, intention, speech, action, livelihood, effort, mindfulness, and concentration.

In the Satipatțhanna Sutta, the Buddha identified mindfulness-non-judgmental present-moment awareness - as an especially helpful path toward overcoming clinging and achieving enlightenment. The Buddha describes how one can build the four establishments of mindfulness, which are awareness of the body (sensation), feeling (emotion), mind (thoughts), and phenomena (other mental activity):

Monks, this is the one-way path for the purification of beings, for the surmounting of sorrow and lamentation, for the passing away of pain and dejection, for the attainment of the true way, for the realization of Nibbāna [Sanskrit: Nirvana]—namely, the four establishments of mindfulness. What are the four? Here monks, a monk dwells contemplating the body in the body, ardent, clearly comprehending, and mindful, having subdued longing and dejection in regard to the world. [The same formula is repeated for feeling, mind, and phenomena.]....And how, monks, does a monk dwell contemplating the body in the body? Here a monk, gone to the forest, to the foot of a tree, or to an empty hut, sits down; having folded his legs crosswise, straightened his body, and established mindfulness in front of him, just mindful he breathes in, mindful he breathes out. [Similar instructions are given for feeling, mind, and phenomena.] ${ }^{7}$

In essence, mindfulness is the opposite of clinging. One is simply, non-judgmentally aware of one's experience, without either chasing after pleasant experiences or avoiding unpleasant experiences. The four foundations of mindfulness—-body, feeling, mind, and phenomenacollectively exhaust the possible objects of experience, so that there is nothing excluded from one's mindful awareness. Later in the same text, the Buddha says that someone who could practice this for seven days would either achieve Nibbāna or would suffer only one further rebirth before achieving enlightenment. ${ }^{8}$

On the surface, it is not obvious what all of this has to do with politics, and for many years Western readers of the early Buddhist texts were influenced by Max Weber's interpretation

\footnotetext{
${ }^{5}$ Over the following two thousand years Buddhism split into numerous sects, and many more teachings were ascribed both to the Buddha and other enlightened teachers. One important doctrinal difference concerns whether it is better to seek one's own enlightenment as quickly as possible (the view held by the Theravāda tradition), or whether someone who has nearly achieved enlightenment should voluntarily accept rebirth to help others escape saṃsāra (the view held by the Mahāyāna and Vajrayāna traditions).

'See Bhikkhu Bodhi, The Connected Discourses of the Buddha: A Translation of the Samyutta Nikāya (Boston: Wisdom Publications, 2000), 56:11, pp. 1843-1847.

${ }^{7}$ Bhikkhu Bodhi (ed.), In the Buddha's Words: An Anthology of Discourses from the Päli Canon, Kindle ed. (Somerville, MA: Wisdom Publications, 2005), pp. 281-282.

${ }^{8}$ Bodhi, In the Buddha's Words, p. 289.
} 
that Buddhism was wholly apolitical. ${ }^{9}$ But, Buddhism has in fact been concerned with politics from the earliest texts through all eras and traditions. The early texts depict a state of nature, in which human society is troubled by theft, dishonesty, and violence, and responds by creating something very like a social contract, in which the people choose a leader to make and enforce laws in exchange for a share of the crops. ${ }^{10}$ That leader becomes the first king, and rule becomes hereditary. ${ }^{11}$ Eventually, a king comes to power who is concerned to make spiritual progress, and he becomes the first wheel-turning king, that is, one whose rule reflects and furthers the moral and spiritual truths revealed by the Buddha. ${ }^{12}$ The wheel is a common Buddhist symbol, rooted in pre-Buddhist sun symbols, ${ }^{13}$ and the title of the Buddha's first sermon translates as "Setting the Wheel of Truth in Motion."14 When spiritually good rulers are in power, society flourishes, and there is little crime or poverty. But inevitably, rulers will falter through ignorance and pride, and when they do, the people suffer and begin to misbehave. Once that cycle begins, it becomes self-reinforcing, until human society reaches a nadir of violence and depravity, which only a handful of less-morally bad people survive. Shocked by events, they commit themselves to moral self-reform, and start the whole process over again, culminating in the rule of another wheel-turning king, and followed by another inevitable decline, ad infinitum. ${ }^{15}$

Until 1850s, all Buddhist traditions supported some version of more-or-less absolute (if hopefully enlightened) monarchy, and all Buddhist-run countries were monarchies. Colonialism destroyed the Buddhist political tradition in some Buddhist-majority countries (Sri Lanka, Laos, Burma/Myanmar), while some others abandoned absolute monarchy on their own or in response to other pressures (Cambodia, Thailand, Bhutan, the government of Tibet in exile), and yet others abandoned Buddhism as their political ideology, either during the peak of colonialism (Japan) or before the colonial era (Vietnam, Korea). In the period between 1850s and roughly 1960s, under the pressure of colonialism and increased global competition, all of the countries that had been Buddhist monarchies in the nineteenth century adopted some form of constitutional, republican government, often with a monarch as head of state, though with much reduced powers. ${ }^{16}$ Some modern scholars view this as a wholesale abandonment of Buddhism as a guide to politics, accompanied by the fabrication of a Buddhist republican tradition from a highly selective reading of the ancient

\footnotetext{
9"Ancient Buddhism represents in almost all practically decisive points the characteristic polar opposite of Confucianism as well as of Islam. It is a specifically unpolitical and anti-political status religi on, more precisely, a religious 'technology' of wandering and of intellectually-schooled mendicant monks" (Max Weber, The Religion of India, trans. Hans H. Gerth and Don Martindale (New York: The Free Press, 1958), p. 206.

${ }^{10} \mathrm{On}$ the question of whether it is appropriate to call this agreement a social contract, see Andrew Huxley, "The Buddha and the Social Contract," Journal of Indian Philosophy 24:4 (1996), pp. 407-420. and Steven Collins, "The Lion's Roar on the Wheel-Turning King: A Response to Andrew Huxley's 'The Buddha and the Social Contract,', Ibid., pp. 421-446.

${ }^{11}$ This part of the story appears in the Aggañña-Sutta; see Maurice Walshe, The Long Discourses of the Buddha: A Translation of the Digha Nikāya (Boston: Wisdom Publications, 1995), pp. 407-415.

${ }^{12}$ This part of the story is told in the Mahäsudassana Sutta; see Walshe, Long Discourses, pp. 279-290.

${ }^{13}$ See Ananda Kentish Coomaraswamy, The Origin of the Buddha Image \& Elements of Buddhist Iconography (Louisville, KY: Fons Vitae, 2006).

${ }^{14}$ Bhikkhu Bodhi, The Connected Discourses of the Buddha: A Translation of the Samyutta Nikāya (Boston: Wisdom Publications, 2000), 56:11, pp. 1843-1847.

${ }^{15}$ See the Cakkavatti-Sïhanāda Sutta at Walshe, Long Discourses, pp. 395-406.

${ }^{16}$ For a more detailed discussion of this history, see Matthew J. Moore, Buddhism and Political Theory (Oxford; New York: Oxford University Press, 2016), Ch. 3, pp. 43-61.
} 
Others argue that Buddhism had always possessed a preference for republicanism, but had been forced by historical circumstances to pretend to favor monarchy. ${ }^{18}$ Yet, others argue that although Buddhist political thought had indeed been primarily monarchical, the ancient texts did contain some republican elements, and that the modern turn toward republicanism represented a change in emphasis and an application of underlying principles to new circumstances. ${ }^{19} \mathrm{I}$ argue at greater length elsewhere that this third interpretation is correct, but unfortunately do not have the space to elaborate that claim here..$^{20} \mathrm{Here}$, I focus on a different but related claim: that Buddhism today has some significant ideological overlap with the American left, but that it is nonetheless unlikely to be a significant ally in transformative politics.

\section{Buddhism, Mindfulness, Politics, and the Left}

Since this turn to republicanism, in the period since 1960, Buddhism has been increasingly associated with progressive or transformative politics, particularly among American and European converts. Thus, for example, in the only systematic, nationwide survey of American Buddhists, sociologist James Coleman found that 60 per cent identified as Democrats, 9.9 per cent as Greens, and only 2.6 per cent as Republicans. ${ }^{21}$ The association of Buddhism with left politics has also been developed through the activism of people such as Vietnamese monk and peace activist Thích Nhất Hạnh, who coined the term "engaged Buddhism" to describe a combination of Buddhist spiritual practice with concern for economic, political, and social justice. ${ }^{22}$ Most recently and prominently, Buddhists were a visible presence in the Occupy Wall Street movement, as detailed in James Rowe's contribution to this symposium. ${ }^{23}$

${ }^{17}$ See: Heinz Bechert, "Aspects of Theravāda Buddhism in Sri Lanka and Southeast Asia," in Tadeusz Skorupski (ed.), The Buddhist Heritage, Buddhica Britannica (Tring: The Institute of Buddhist Studies, 1989), pp. 19-27; "S.W.R.D. Bandaranaike and the Legitimation of Power through Buddhist Ideals," in Bardwell L. Smith (ed.), Religion and Legitimation of Power in Sri Lanka, (Chambersburg, PA: ANIMA Books, 1978), pp. 199-211; Emanuel Sarkisyanz, "Buddhist Background of Burmese Socialism," in Bardwell L. Smith (ed.) Religion and Legitimation of Power in Thailand, Laos, and Burma (Chambersburg, PA: ANIMA Books, 1978), pp. 87-99.

${ }^{18}$ See: Joanna Rogers Macy, "Dependent Co-Arising: The Distinctiveness of Buddhist Ethics," Journal of Religious Ethics 7:1 (1979), pp. 38-52; Trevor Ling, "Kingship and Nationalism in Pali Buddhism," in Philip Denwood and Alexander Piatigorsky (eds), Buddhist Studies: Ancient and Modern, Collected Papers on South Asia (London; Dublin: Curzon Press, 1983), pp. 60-73; Anthony Kennedy Warder, Indian Buddhism, $1^{\text {st }}$ ed. (Delhi: Motilal Banarsidass, 1970); Laksiri Jayasuriya, "Buddhism, Politics, and Statecraft," International Journal of Buddhist Thought \& Culture 11 (2008), pp. 41-74; Kulatissa Nanda Jayatilleke, "Principles of International Law in Buddhist Doctrine," Recueil des Cours 120 (1967), pp. 441-567.

${ }^{19}$ See Donald Eugene Smith, Religion and Political Development (Boston: Little, Brown and Company, 1970); Richard A. Gard, "Buddhism and Political Authority," in Harold D. Lasswell and Harlan Cleveland (eds), The Ethic of Power: The Interplay of Religion, Philosophy, and Politics, (New York: Harper \& Brothers, 1962), pp. 39-70; Aung San Suu Kyi, Freedom from Fear and Other Writings (London; New York: Viking, 1991); Tenzin Gyatso (His Holiness the Fourteenth Dalai Lama), "Buddhism and Democracy," The Office of His Holiness the Dalai Lama, available online at: < http://www.dalailama.com/messages/buddhism/buddhism-and-democracy>; Stanley Jeyaraja Tambiah, Buddhism Betrayed? Religion, Politics, and Violence in Sri Lanka (Chicago; London: University of Chicago Press, 1992).

${ }^{20}$ See Moore, Buddhism and Political Theory, Ch. 3, pp. 43-61.

${ }^{21}$ James W. Coleman, The New Buddhism: The Western Transformation of an Ancient Tradition (Oxford; New York: Oxford University Press, 2001), p. 193.

${ }^{22}$ See Rita M. Gross, "Being Benevolence: The Social Ethics of Engaged Buddhism (Review)," Buddhist-Christian Studies 27:1 (2007), pp. 174-179; Ken Jones, The New Social Face of Buddhism: A Call to Action (Boston: Wisdom Publications, 2003); Sallie B. King, "An Engaged Buddhist Response to John Rawls's Law of Peoples," Journal of Religious Ethics 34:4 (2006), pp. 637-661; Christopher S. Queen (ed.), Engaged Buddhism in the West (Boston, MA: Wisdom Publications, 2000); Action Dharma: New Studies in Engaged Buddhism (London: RoutledgeCurzon, 2003); "Socially Engaged Buddhism: Emerging Patterns of Theory and Practice," in Steven M. Emmanuel (ed.), A Companion to Buddhist Philosophy, (New York: John Wiley \& Sons, Inc., 2013), pp. 524-535; Christopher S. Queen and Sallie B. King (eds), Engaged Buddhism: Buddhist Liberation Movements in Asia (Albany: State University of New York Press, 1996).

${ }^{23}$ See also: James K. Rowe,"Zen and the Art of Social Movement Maintenance,"Waging Non-Violence (2015), available online at: < http://wagingnonviolence.org/feature/mindfulness-and-the-art-of-social-movement-maintenance/>. 
There are indeed some obvious connections between Buddhism and progressive left politics. Buddhism advocates several principles that have been central to the American and European left in the period after World War II. Thus, Buddhism advocates non-violence and pacifism (because violence and war are both rooted in selfish delusion and contribute greatly to human suffering) ${ }^{24}$ It appears to advocate for something like the welfare state-indeed, the would-be wheel-turning king whose errors cause society to tip irrevocably into decline makes the fateful mistake when he fails to provide adequate support for the poor, who are then driven to crime to supply their needs. The Buddhist monastic community, the sangha, traditionally operated as a directly democratic community (albeit with a hierarchy of seniority and experience to which deference was expected) that made decisions by consensus. Buddhism argued for the moral equality of all people centuries before Jesus of Nazareth did (even if the practices of the sangha retained some troubling inequalities between men and women). Buddhists have traditionally been vegetarians, ${ }^{25}$ argued for treating non-human animals as morally equal to human beings (because animals are also part of the cycle of reincarnation), and long urged a respectful, sustainable human relationship with nature. Finally, the asceticism in Buddhism, especially in the monastic tradition, clearly stands opposed to the ego-driven, consumerist culture of the modern West that many on the left have decried as ecologically unsustainable, intellectually shallow, and morally vacuous. For all of those reasons, Buddhism seems like a good ally for the left.

And yet, there are some reasons to be cautious about seeing Buddhism as part of the political left or even as a promising ally. One set of concerns is philosophical: Buddhism comes with baggage that makes it an uneasy fit with a progressive left agenda, and which many European and American Buddhists have simply ignored. Every Buddhist tradition believes in reincarnation not as a metaphor or an analogy, but as a fact of human existence. Further, although American Buddhists rarely talk this way, the Buddhist doctrine of kamma/ karma inherits from its Vedic ancestor the troubling implication that people who are born into lowly social positions, or who suffer greatly in life, are to some degree merely reaping the kammatic consequences of their own prior misdeeds. Even though many Buddhists, such as Thích Nhất Hạnh, identify bad government, social and economic inequality and injustice, and other remediable, human failings as the causes of much pain and suffering in the world, for kamma to have any effect or relevance, some human suffering must be the result of the sufferer's prior misdeeds, and in that sense must be, if not deserved, at least appropriate and necessary for that person's future spiritual progress. Further, the ancient texts repeatedly discourage practitioners from active involvement in politics, for example by prohibiting monastics from discussing politics or current events such as wars or controversies, ${ }^{26}$ and prohibiting the sangha from ordaining anyone currently under obligation to the military or undergoing a criminal punishment. ${ }^{27}$ The Buddha himself rejected the opportunity to become a wheel-turning monarch on the grounds that it would be less valuable than his spiritual mission, ${ }^{28}$ and his most advanced lay disciple similarly rejected

\footnotetext{
${ }^{24}$ See Walpola Rahula, What the Buddha Taught, Second, revised ed. (New York: Grove Press, 1974).

${ }^{25}$ Rather, Buddhists are mostly vegetarian-because Buddhist monastics traditionally beg for their food, they are permitted (indeed, required) to eat what is offered to them, unless it is the meat of an animal that has been killed specifically for them. 26"Bhikkhus [monks], do not engage in the various kinds of pointless talk, that is, talk about kings, thieves, and ministers of state; talk about armies, dangers, and war..." Bodhi, Connected Discourses, p. 1843.

${ }^{27}$ See The Book of the Discipline, trans. I.B. Horner, VI vols., vol. IV (Oxford: The Pali Text Society, 1940), p. 95.

${ }^{28}$ See Connected Discourses, 4:20, pp. 209-210.
} 
a future incarnation as a wheel-turner, on the grounds that such a life would merely distract him from making further spiritual progress. ${ }^{29}$ This historical concern about politics interfering with spiritual life has continued into the present. For example, in the survey of American Buddhists mentioned above, James Coleman found that the majority did not want their Buddhist groups to become more involved in politics, and activist Buddhists were a small minority. ${ }^{30}$

A second reason to be cautious about the possible usefulness of Buddhism for the left is that, while Buddhism and Buddhists might be good allies for progressives, and while some progressives may individually become Buddhists or adopt various Buddhist-inspired practices, Buddhism is a marginal cultural phenomenon in the United States (US) and Europe, and is not in a position to make more than a tiny contribution to any movement toward a left agenda. In 2010s, 1.2 per cent of the US population was Buddhist, and in Europe the number was 0.2 per cent. ${ }^{31}$

This raises the question of whether the American left might get more traction from the larger but vaguer interest in mindfulness. In the 1980s, the American Buddhist JonKabat Zinn popularized the term "mindfulness" for the practice of non-judgmental present-moment awareness as a therapeutic and self-actualization technique separated from its Buddhist roots and entanglements. He pioneered Mindfulness-Based Stress Reduction (MBSR), a method of learning to cope with pain and chronic illness through non-judgmental awareness of one's experience. In part because of the success of MBSR, the practice of mindfulness has become increasingly visible in popular culture. For example, Time magazine's lead story in its January 23, 2014 issue was "The Mindful Revolution." Google's Ngram tool, which calculates the frequency with which words appear in books over time, shows that use of the word "mindfulness" increased roughly 225 per cent between 1980s and 2000 s (the most recent year for which data are available). ${ }^{32}$ Similarly, analysis of Google search data shows that searches for "mindfulness" increased nearly tenfold between February 2014 and January $2016 .{ }^{33}$ The WorldCat database of the holdings of libraries worldwide shows 187 books with a keyword "mindfulness" published between 1980 and 1989, 512 published between 1990-1999, 2093 from 2000-2009, and 4878 between 2010 and $2016 .^{34}$

The possibility of a connection between mindfulness and politics has also received a growing degree of attention. In recent years, there have been several books published on mindfulness and politics, such as Melvin McLeod's Mindful Politics, ${ }^{35}$ US Congressman Tim Ryan's A Mindful Nation, ${ }^{36}$ and Kabat-Zinn's Coming to Our Senses: Healing Ourselves and the World Through Mindfulness. ${ }^{37}$ The US Congress now has an informal Quiet Time Caucus, which

\footnotetext{
${ }^{29}$ See lbid., 41:10, p. 1330.

${ }^{30}$ Coleman, The New Buddhism: The Western Transformation of an Ancient Tradition, pp. 227-228.

${ }^{31}$ The Pew Forum on Religion \& Public Life, The Global Religious Landscape, p. 50.

${ }^{32}$ See <https://books.google.com/ngrams> (accessed January 27, 2016).

${ }^{33}$ See $<$ http://www.google.com/trends/explore > (accessed January 27, 2016).

${ }^{34}$ These data are only illustrative, because a number of factors affect the results, including the fact that newer titles are more likely to have keywords as part of their library record and that libraries are more likely to collect newer titles.

${ }^{35}$ Melvin McLeod, Mindful Politics: A Buddhist Guide to Making the World a Better Place (Boston: Wisdom Publications, 2006).

${ }^{36}$ Tim Ryan, A Mindful Nation: How a Simple Practice Can Help Us Reduce Stress, Improve Performance, and Recapture the American Spirit, $1^{\text {st }}$ ed. (Carlsbad, CA: Hay House, 2012).

${ }^{37}$ Jon Kabat-Zinn, Coming to Our Senses: Healing Ourselves and the World through Mindfulness (New York: Hyperion, 2005).
} 
meets to meditate weekly, ${ }^{38}$ and the British Parliament has an All-Party Parliamentary Group on Mindfulness. ${ }^{39}$

Although we can only speculate about this, it seems very likely that the popularity of mindfulness is due in part to its independence from the Buddhist tradition from which it sprang. Mindfulness, like yoga, today is frequently promoted as a technique that can be practiced by people who profess any faith or no faith, and it is free of metaphysical, historical, and political baggage. Buddhism may have spent two thousand years advocating absolutist monarchy, but mindfulness has not, and the question of what political implications mindfulness may have is currently wide open. In particular, it is not yet clear whether mindfulness will appeal to and be associated with the political left, as Buddhism has, or whether it will become a more neutral, technical practice with no particular political flavor, again like yoga has become. This raises the question of whether the rising popularity of mindfulness is an opportunity for the political left to broaden its appeal and make new alliances, or whether it will instead be another example of an issue nurtured in a progressive counter-culture and then commodified, genericized, and depoliticized to make it appealing to a broader audience, like organic food.

Although we obviously cannot predict the future with great accuracy, we can analyze the idea of mindfulness itself and explore what appear to be its likely implications for politics. First, what have advocates of using mindfulness in politics themselves said? Jon Kabat-Zinn emphasizes that mindfulness practice could influence politics primarily by helping individuals to become less reactive, less stressed, and less caught up in self-righteousness:

Cultivating greater mindfulness in our lives does not imply that we would fall into one set of ideological views and opinions or another, but that we might see more freshly for ourselves, with eyes of wholeness, moment by moment. But what mindfulness can do for us, and it is a very important function, is reveal our opinions, and all opinions, as opinions, so that we will know them for what they are and perhaps not be so caught by them and blinded by them, whatever their content... ${ }^{40}$

Similarly, Tim Ryan, who identifies Kabat-Zinn and his work as an inspiration, mostly focuses on what we might call emotional and process benefits that might arise from applying mindfulness to politics:

We may see the humor in our mistakes and be able to laugh at ourselves more. We may be just a little less critical of others, and of ourselves. Or we may deal with our mistakes more quickly and with a more sincere and kind heart. We may more easily forgive the people who have hurt us. We may sit down and have civil political conversations with those who strongly disagree with us. ${ }^{41}$

Both Kabat-Zinn and Ryan see mindfulness as a process of self-investigation, and envision its impact on politics as arising from how it changes the people who engage in politics. Their analysis also suggests that we might expect to see changes in two main areas: practitioners' dispositions and their beliefs. Thus, Ryan suggests that if we practice mindfulness, our dispositions may change by becoming less critical, more humble, and more open, and Kabat-Zinn suggests that we might see changes in the contents of our beliefs and/or in how we hold them. Their comments on what changes might occur, and

\footnotetext{
${ }^{38}$ Alex Seitz-Wald, "Meet the 'Mindfulness' Caucus: Politicians Who Meditate!," Salon.com, available online at: <http://www. salon.com/2013/07/10/meet_the_buddhist_caucus/>.

${ }^{39}$ Ed Halliwell,"Can Mindfulness Transform Politics?,"Mindful, available online at: <http://www.mindful.org/the-mindful-society/ can-mindfulness-transform-politics>.

${ }^{40}$ Kabat-Zinn, Coming to Our Senses, pp. 508-509.

${ }^{41}$ Ryan, A Mindful Nation, p. 167.
} 
how likely they might be, are intriguing but preliminary. In this section, I examine them in greater depth.

First, it is important to notice that people have some beliefs and dispositions that are directly related to politics, and others that are general and not directly concerned with politics. On this view, non-political beliefs are descriptive beliefs about the world with no obvious (direct) connection to politics, government, or policy choices. Such beliefs might touch on the questions of the nature of identity (am I an atomistic self or a manifestation of a greater, holistic something?), the functioning of causality, the existence of an afterlife, and similar topics. Non-political disposition refers to one's general approach to life, problems, conflict, decisions, and so on, without direct reference to politics. Thus, if one is generally rational or emotional, happy or sad, confident or uncertain, social or solitary, all count as parts of one's non-political disposition. In contrast, one's political disposition is how one is inclined to act in specifically political contexts. For example, we can easily imagine someone who is congenial and conciliatory at home but pugnacious and partisan at a town-hall meeting, or when discussing certain political topics. Finally, one's political beliefs are all those beliefs either about or directly relevant to politics, including one's normative beliefs generally, because many of one's normative beliefs will be directly relevant to political questions. Thus, political beliefs could include things such as the belief that members of a particular political party are scoundrels and knaves as well as the belief that violence of any kind is deeply morally wrong.

What effects might mindfulness practice have on these four aspects of personality? It certainly seems possible that mindfulness practice might lead someone to change their non-political, non-normative beliefs. Mindfulness practitioners frequently report that their practice leads them to see personal identity as more porous and unstable than they previously thought, or to come to believe that every phenomenon is both the result of innumerable previous causes and a partial cause of innumerable future phenomena, such that the universe is united in a complex web of interdependence. ${ }^{42}$ Such changes in belief might, in turn, affect one's non-political disposition, for example by making one happier, less anxious, or less afraid of death.

It also seems possible that changes in one's non-political disposition might lead to changes in one's political disposition. Such changes might be due to changes in one's beliefs (as above), or they might be their own independent phenomenon: for example, perhaps mindfulness practice leads me to become happier or less stressed, and that leads me to be more tolerant of disappointment and frustration. Would such changes be likely to change one's political dispositions? We have to consider two possibilities. In the first, the person in question does not make any distinction between political and non-political contexts, such that their disposition is always the same. In that case, their behavior in political contexts will change if their overall disposition changes. That seems like a reasonable conclusion: if mindfulness makes people nicer, for example, then it seems reasonable to think that it should make them nicer in all contexts.

In the second possibility, the practitioner does distinguish between the two contexts, and they have different dispositions when they act politically and when they act non-politically. In that case, while it seems plausible, even likely, that changes to their non-political disposition would affect their political behavior in some way, there is no reason to think that mindfulness practice would lead them to modify or abandon the political/non-political distinction, and

${ }^{42}$ For example, see Ethan Nichtern, One City: A Declaration of Interdependence (Boston: Wisdom Publications, 2007). 
there is no reason to think that changes to their non-political disposition would change their political behavior in different ways than it would change their non-political behavior. Thus, they might be nicer to everyone, but there is no reason to think that they would be even nicer to people who had previously been their political opponents, nor conversely that they would be nicer to everyone except them. Similarly, if previously they had had the disposition that it was good to be agreeable except when important political issues were at stake, there is no reason to think that their new attitude would erase that distinction, though it might make them more agreeable, to different degrees, in both kinds of situations. Thus, changes to one's non-political disposition might lead to changes in one's political disposition, but the two dispositions seem likely to remain distinct if they started out that way.

Is it likely that mindfulness practice would lead directly to changes in one's political disposition (assuming that one has one distinct from one's non-political disposition)? To distinguish this question from the issues already considered, here, the question is whether one's political disposition would change independently of changes to one's non-political beliefs or non-political disposition. Thus, for example, I would have to become disposed to be more trusting of my political opponents but not because I had become disposed to be more trusting of everyone, nor because I changed my beliefs about, for example, human nature. Here, I think, it seems completely plausible that mindfulness practice might change my disposition. Perhaps, mindfulness will help me realize that I am especially inflexible in political contexts because I am afraid that the power of government will be used against me. It is a familiar experience that recognizing and being able to articulate a fear often results in the fear becoming less powerful. Thus, I might become less fearful, and consequently less inflexible. Obviously, this change does not arise because my fear is related to politics but rather because mindfulness may be especially helpful at teaching us to recognize and cope with fear, and my particular fear happens to arise in the context of politics.

To summarize the argument so far, it seems reasonable to think that mindfulness practice might lead to changes in our non-political beliefs, non-political disposition, and political disposition, either directly or by inciting changes in one area (non-political disposition) that spread to another (political disposition). But, now we get to what I think is the hardest question: is mindfulness likely to change one's political (and normative) beliefs? Here, I think the answer depends on what those beliefs rest upon. Thus, we can imagine that some beliefs ultimately rest on personal feelings or habits, some upon factual beliefs, and some upon what for the moment I want to call existentially basic beliefs. For example, I might believe (more or less consciously) that members of a particular social group are generally good and trustworthy people primarily because I have had pleasant experiences with some members of that group, and those experiences have given the group a positive emotional valence in my mind. In contrast, I might believe that members of some social group are unusually likely to be engaged in criminal activity because of what (I think) I know about arrest and conviction statistics. Finally, I might believe that members of some socially disfavored group deserve greater respect and/or equality because I am committed as a matter of principle to treating all people as equally worthy of respect and as deserving a chance to flourish. (The distinction among emotional, factual, and existential beliefs is intended to be illustrative rather than categorical; presumably most of our beliefs in fact blend all three elements together and include various unconscious and non-discursive elements as well.)

Given those distinctions, it seems plausible that mindfulness practice could affect beliefs rooted in emotion, primarily by making the basis of the beliefs more accessible to conscious 
recognition and evaluation. That does not necessarily mean that such beliefs would change, but only that it seems plausible that they might change. In contrast, it seems less likely that mindfulness practice would affect beliefs based on factual information. Indeed, if anything, it seems more likely that mindfulness would reinforce fact-based beliefs, by encouraging conscious recognition of and reflection on the underlying facts and their relationship to the belief. To the extent that the facts are false, or that our understanding of the facts is influenced by emotion, then change becomes more likely, but beliefs rooted in true facts whose recognition is relatively free of emotional distortion seem unlikely to be affected.

By "existentially basic"I mean normative beliefs fundamental to our understanding of the world. (There are also non-normative beliefs that are existentially basic, but for our purposes they are included in the non-political beliefs category). Although such beliefs are obviously influenced by emotions and facts, they are not logically derived from them. For example, following David Hume (and G.E. Moore), ${ }_{1}^{43}$ the wrongness of murder does not appear to depend logically either on our feelings about murder or on any facts about murder (that it makes others deeply unhappy, that it is socially disruptive, and so on). Even in a case in which the facts or the feelings were different, most people are inclined to say, murder would still be wrong.

It seems very unlikely that mindfulness practice would affect such existentially basic beliefs. On the one hand, such beliefs are foundational to our understanding of the moral universe. Changing them would require a significant reorganization of our moral personalities, which experience suggests is rare (if not impossible). On the other hand, because such beliefs are not logically dependent on other, non-fundamental beliefs or feelings, changes to our other beliefs, or to our disposition, seem unlikely to change our existentially basic beliefs. Indeed, it seems more likely that mindfulness practice would deepen and strengthen our commitment to our existentially basic beliefs. Paying careful attention to our experience, and learning to distinguish between transient emotions and more durable beliefs, seems likely to make the beliefs relatively more important. Obviously, this is not to say that no changes to our existentially basic beliefs ever happen, nor to deny that they might sometimes happen as a result of mindfulness practice, but only to argue that there is no reason to think that mindfulness practice is likely to result in such changes.

Earlier I emphasized that Kabat-Zinn and Ryan are focused on mindfulness as an experience of oneself. From that perspective, mindfulness is a phenomenological practiceit examines our experience as experience, but does not make claims about connections between our experience and experience-independent reality. Thus, I may learn that I believe some things very strongly, or that those beliefs have a strong influence on my attitudes or behavior, but neither insight tells me whether my beliefs are true.

I believe that this may be a place where mindfulness separated from its Buddhist roots poses a danger. The Buddhist tradition emphasizes that human beings are subject to three forms of error-greed, hatred, and delusion - that cause endless problems (indeed, they cause all problems). It also emphasizes that neither personal identity nor any aspect of experience, either object or belief, is permanent-everything is temporary and insubstantial. ${ }^{44}$ Although human beings obviously must nevertheless act and choose, Buddhism counsels

\footnotetext{
${ }^{43}$ See David Hume, A Treatise of Human Nature (Oxford: Oxford University Press, 2000); G.E. Moore, Principia Ethica, Revised ed. (Cambridge: Cambridge University Press, 1993).

${ }^{44} \mathrm{See}$ the discussion of the three marks (or characteristics) of existence in the Dhamma-niyama Sutta of the AnguttaraNikäya (III: 134); see The Book of the Gradual Sayings (Anguttara-Nikäya) or More-Numbered Sayings, trans. E.M. Hare, V vols., vol. IV (Oxford: Pali Text Society, 1935), pp. 264-265.
} 
caution and humility, rather than certainty and boldness. The danger of a practice of mindfulness divorced from these other beliefs is that the practitioner may conclude that what they learn about their own experience is in fact a reflection of experience-independent reality. For example, if through my mindfulness practice I notice that many of my beliefs and dispositions are variable and unstable, but two or three beliefs are consistent and ever-present, I may conclude that those beliefs are not merely central to my experience but true. To the extent that this happens, mindfulness may have the effect, contrary to the hopes of Ryan and Kabat-Zinn, of making me less humble, less flexible, less tolerant, and less willing to engage with people who believe different things. That seems likely to lower my estimate of my opponents (who after all disagree with me only because they fail to perceive what is true), and to increase the likelihood of conflict and deadlock.

Thus, overall, mindfulness seems capable of affecting politics by affecting practitioners' dispositions and beliefs. However, it seems very unlikely to change someone's considered or foundational beliefs, and if approached as a truth-revealing activity rather than an experience-revealing activity, may reinforce both the content of those beliefs and the certainty with which they are held.

\section{Conclusion}

Do the growing popularities of Buddhism or mindfulness represent an opportunity for the left? If the analysis I presented earlier is roughly correct, then Buddhism does appear to have some (though not perfect) ideological overlap with the American left, but the number of American Buddhists remains very small. If Buddhism were to become attractive to many more Americans, that would probably be good news for progressives, but at the moment there does not seem to be any great strategic opportunity. Mindfulness as a technique separated from its Buddhist roots appears to be growing quickly, and its non-ideological and instrumental profile may allow it to become a much larger American cultural phenomenon than Buddhism. Its origin in Buddhism may make its appear to be of similar potential interest for the left, but the analysis presented above suggests that it may not really be so. Because mindfulness seems unlikely to change people's fundamental values or beliefs, wider practice of mindfulness would not be likely to bring otherwise unsympathetic Americans closer to the left, and there is a real danger that it may encourage greater ideological rigidity and conflict. Thus, the "mindfulness revolution" appears likely to be politically neutral, though hopefully it will be of genuine personal help to its practitioners.

\section{Disclosure statement}

No potential conflict of interest was reported by the author.

\section{Notes on contributor}

Matthew J Moore is Associate Professor of Political Science at California Polytechnic State University in San Luis Obispo. He is the author of Buddhism and Political Theory (Oxford, 2016), and has also written on value pluralism, the philosophy of Ludwig Wittgenstein, and political theory as a discipline. 